\title{
Xylem water potentials of native shrubs from northeastern Mexico
}

ARTICLE in ACTA AGRICULTURAE SCANDINAVICA, SECTION B - SOIL \& PLANT SCIENCE · APRIL 2011

Impact Factor: 0.65 · DOI: 10.1080/09064711003693211

CITATIONS

2
DOWNLOADS

49
VIEWS

165

8 AUTHORS, INCLUDING:

\section{H. González-Rodríguez}

Autonomous University of Nuevo León

76 PUBLICATIONS 148 CITATIONS

SEE PROFILE

\section{Marco Vinicio Gómez-Meza}

Autonomous University of Nuevo León

43 PUBLICATIONS 108 CITATIONS

SEE PROFILE

\section{Roque Gonzalo Ramírez-Lozano}

Autonomous University of Nuevo León

114 PUBLICATIONS 474 CITATIONS

SEE PROFILE

Ratikant Maiti

R.K. MAITI RESEARCH FOUNDATION

38 PUBLICATIONS 151 CITATIONS

SEE PROFILE 
This article was downloaded by: [González-Rodríguez, Humberto]

On: 8 April 2011

Access details: Access Details: [subscription number 936122778]

Publisher Taylor \& Francis

Informa Ltd Registered in England and Wales Registered Number: 1072954 Registered office: Mortimer House, 3741 Mortimer Street, London W1T 3JH, UK

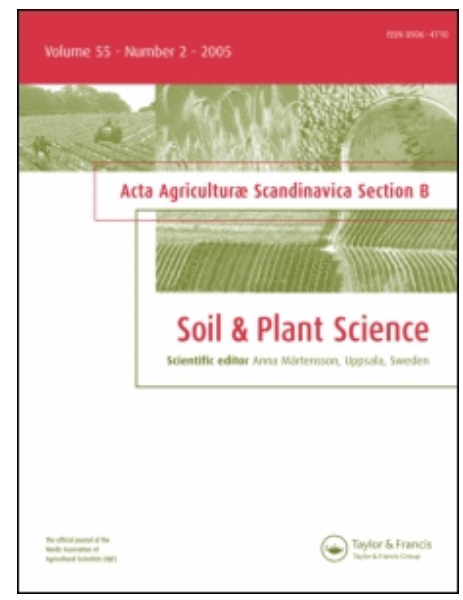

\section{Acta Agriculturae Scandinavica, Section B - Plant Soil Science}

Publication details, including instructions for authors and subscription information:

http://www.informaworld.com/smpp/title $\sim$ content=t713394126

\section{Xylem water potentials of native shrubs from northeastern Mexico}

H. González-Rodríguez; ; I. Cantú-Silva ; R. G. Ramírez-Lozano ; M. V. Gómez-Mezac; J. SarquisRamírez $^{\mathrm{d}}$; N. Coria-Gil ${ }^{\text {; }}$ J. R. Cervantes-Montoya ${ }^{\mathrm{e}}$; R. K. Maiti ${ }^{\mathrm{f}}$

${ }^{a}$ Universidad Autónoma de Nuevo León, Facultad de Ciencias Forestales, Linares, NL, México ${ }^{\mathrm{b}}$ Universidad Autónoma de Nuevo León, Facultad de Ciencias Biológicas, Monterrey, NL, México ${ }^{c}$

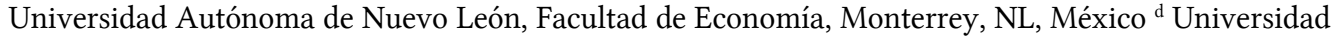
Veracruzana, Facultad de Ciencias Biológicas-Agropecuarias, Peñulea, Córdoba, Veracruz, México ${ }^{\text {e }}$ Universidad Autónoma de Sinaloa, Escuela Superior de Agricultura del Valle del Fuerte, Los Mochis, Sinaloa, México ${ }^{\mathrm{f}}$ Vibha Seeds, Vibha Agrotech Ltd, Hyderabad, Andhra Pradesh, India

First published on: 09 March 2011

To cite this Article González-Rodríguez, H. , Cantú-Silva, I. , Ramírez-Lozano, R. G. , Gómez-Meza, M. V. , SarquisRamírez, J. , Coria-Gil, N. , Cervantes-Montoya, J. R. and Maiti, R. K.(2011) 'Xylem water potentials of native shrubs from northeastern Mexico', Acta Agriculturae Scandinavica, Section B - Plant Soil Science, 61: 3, 214 - 219, First published on: 09 March 2011 (iFirst)

To link to this Article: DOI: $10.1080 / 09064711003693211$

URL: http://dx.doi.org/10.1080/09064711003693211

\section{PLEASE SCROLL DOWN FOR ARTICLE}

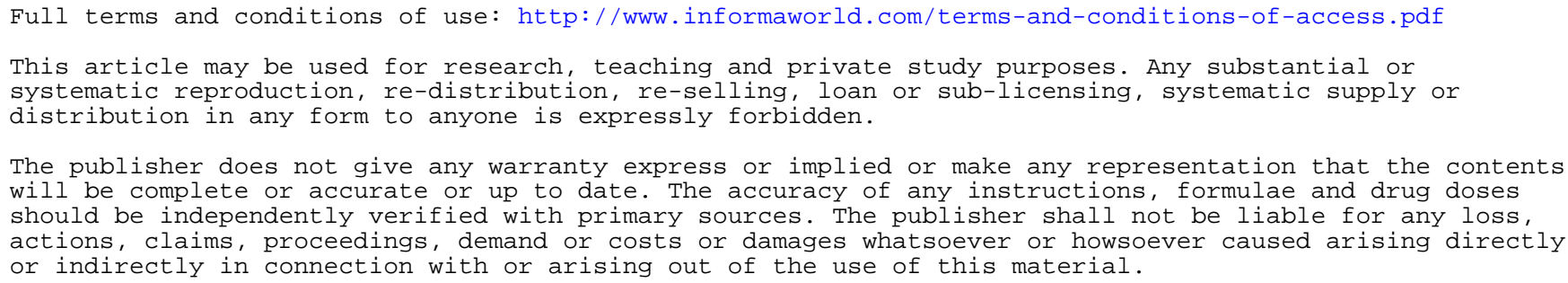




\title{
Xylem water potentials of native shrubs from northeastern Mexico
}

\author{
H. GONZÁLEZ-RODRÍGUEZ ${ }^{1}$, I. CANTÚ-SILVA ${ }^{1}$, R.G. RAMÍREZ-LOZANO², \\ M.V. GÓMEZ-MEZA ${ }^{3}$, J. SARQUIS-RAMÍREZ ${ }^{4}$, N. CORIA-GIL ${ }^{4}$, \\ J.R. CERVANTES-MONTOYA ${ }^{5} \&$ R.K. MAITI ${ }^{6}$
}

${ }^{1}$ Universidad Autónoma de Nuevo León, Facultad de Ciencias Forestales, Linares, NL, México, ${ }^{2}$ Universidad Autónoma de Nuevo León, Facultad de Ciencias Biológicas, Monterrey, NL, México, ${ }^{3}$ Universidad Autónoma de Nuevo León, Facultad de Economía, Monterrey, NL, México, ${ }^{4}$ Universidad Veracruzana, Facultad de Ciencias Biológicas-Agropecuarias, Peñulea, Córdoba, Veracruz, México, ${ }^{5}$ Universidad Autónoma de Sinaloa, Escuela Superior de Agricultura del Valle del Fuerte, Los Mochis, Sinaloa, México, ${ }^{6}$ Vibha Seeds, Vibha Agrotech Ltd, High Tech City Road, Madhapur, Hyderabad 500081, Andhra Pradesh, India

\begin{abstract}
Xylem water potentials $(\Psi)$ were evaluated in browse plants such as Forestiera angustifolia (Oleaceae), Celtis pallida (Ulmaceae), Zanthoxylum fagara (Rutaceae), and Eysenhardtia texana (Fabaceae). Collections were carried out at Linares County, a semi-arid region of northeastern Mexico. $\Psi(\mathrm{MPa})$ were estimated at 10-day intervals between July 10 and September 30, 2008 by using a Scholander pressure bomb, and were monitored in five different plants per species at 06:00 $\mathrm{h}$ (predawn) and 14:00 h (midday). Air temperature, relative humidity, precipitation, and soil water content were registered throughout. Data were subjected to one-way ANOVA and linear correlation analysis. At the wettest period, $\Psi$ at predawn varied from -0.29 (C. pallida and E. texana) to -0.37 (F. angustifolia and Z. fagara); in contrast, at the driest period, predawn $\Psi$ ranged from -3.28 ( $F$. angustifolia) to -4.50 ( $Z$. fagara). At midday $E$. texana achieved the highest $(-1.14)$ and lowest $(-4.20)$ values at wettest and driest sampling dates, respectively. It seems that air temperature and vapor pressure deficit negatively influenced $\Psi$ values in all species; conversely, $\Psi$ values augmented as relative humidity increased. Since $F$. angustifolia and $C$. pallida maintained higher predawn and midday $\Psi$ values under water stress, these species may be considered as drought-adapted species while, $Z$. fagara and E. texana that acquired lower values, may be less adapted to drought and in physiological disadvantage under limited water conditions.
\end{abstract}

Keywords: Celtis pallida, Eysenhardtia texana, Forestiera angustifolia, water potential, Zanthoxylum fagara.

\section{Introduction}

Vegetation of northeastern Mexico is characterized by an average annual precipitation that varies from 400 to $800 \mathrm{~mm}$ and a yearly potential evapotranspiration of about $2200 \mathrm{~mm}$, and has been utilized as a forage source for domestic livestock and wildlife, fuel wood, timber for construction, and medicine (Reid et al., 1990; McMurtry et al., 1996). The great diversity of native shrub species in this region reflects the plasticity among these species derived from their development of effective mechanisms to cope with seasonal water stress. Therefore, shrub and tree plants have evolved key morphological and physiological traits suited for adaptation to environmental constraints, especially on drought-prone sites. The strategies include early leaf abscission, limited leaf area, an extensive and deeper root system, epidermal wax deposition, associated with reduction of water loss by stomatal closure and accumulation of organic and inorganic solutes (Newton et al., 1991).

The study of native species in this region provides an opportunity to investigate ecophysiological aspects of shrub species and their responses to changes in resource availability, particularly soil moisture content, in order to gain a better understanding of how to sustain and improve productivity. However, only three scientific publications (Stienen et al.,

Correspondence: Professor R.G. Ramírez-Lozano, Facultad de Ciencias Biológicas, Universidad Autónoma de Nuevo León, Ave. Universidad S/N, Cd. Universitaria, San Nicolás de los Garza, N.L., 66450, México. Tel: +528183294110. Fax: +528183294049. E-mail: roqramir@gmail.com 
1989; González et al., 2000, 2004) are available on plant water relations of native species of the northeastern region of Mexico. The objectives of this study were to assess xylem water potentials and estimate the relationship between plant water potentials with soil water availability and evaporative demand components in four native shrub species.

\section{Materials and methods}

\section{Research site}

This study was carried out at the Experimental Research Station of Facultad de Ciencias Forestales, Universidad Autónoma de Nuevo León $\left(24^{\circ} 47^{\prime} \mathrm{N}\right.$; $99^{\circ}$ $32^{\prime}$ W; elev. $350 \mathrm{~m}$ ) in Linares county, Nuevo Leon, Mexico. Climate is subtropical and semi-arid with a warm summer. Mean monthly air temperature ranges from $14.7^{\circ} \mathrm{C}$ in January to $22.3^{\circ} \mathrm{C}$ in August. Average annual precipitation is about $800 \mathrm{~mm}$. The main type of vegetation is known as the Tamaulipan Thornscrub or Subtropical Thornscrub Woodlands (SPP-INEGI 1986). The dominant soils are deep, dark-gray, limeclay vertisols, with montmorillonite, which shrink and swell noticeably as soil moisture content varies.

\section{Plant material and water potential measurements}

Five plants of the shrub species Forestiera angustifolia Torr. (Oleaceae; evergreen shrub with stiff and dense branches), Celtis pallida Torr. (Ulmaceae; evergreen and spiny shrub with oval and smooth-edged leaves), Zanthoxylum fagara L. Sarg. (Rutaceae; evergreen shrub bearing recurved and sharp thorns with compound leaves), and Eysenhardtia texana (Ort.) Sarg. (Fabaceae; non-thorny deciduous shrub; mycrophyllous compound leaves) were randomly selected in a $20 \mathrm{~m} \times 20 \mathrm{~m}$ previously established (González et al., 2004) and undisturbed experimental thorn-scrub plot for xylem water potential $(\Psi$, $\mathrm{MPa}$ ) determinations. Being that predawn and midday $\Psi$ measurements are influenced by environmental conditions and with the purpose to detect changes in the plant water relations status, measurements were conducted at 10-day intervals between July 10 and September 30, 2008. The $\Psi$ measurements were taken from terminal twigs at $06: 00 \mathrm{~h}$ (predawn, $\Psi$ pd) and 14:00 h (midday, $\Psi \mathrm{md}$ ). Water potential was estimated using a Scholander pressure bomb (Model 3005, SoilMoisture Equipment Corp., Santa Barbara, CA) (Ritchie \& Hinckley, 1975). One terminal shoot, with fully expanded leaves, was excised and sampled from the middle and shaded side of each plant. As an approach to characterize diurnal $\Psi$ status among studied shrub species, $\Psi$ measurements in each species were taken on Jul-10,
Aug-10, Aug-30, and Sep-30, 2008 at 06:00, 08:00, 10:00, 12:00, 14:00, 16:00, and 18:00 h.

\section{Environmental data}

Air temperature $\left({ }^{\circ} \mathrm{C}\right)$ and relative humidity (\%) were registered on a daily basis using a HOBO Pro Data Logger (HOBO Pro Temp/RH Series, Forestry Suppliers, Inc., Jackson, MS, USA). Daily precipitation $(\mathrm{mm})$ was obtained from a Tipping Bucket Rain Gauge (Forestry Suppliers, Inc.). Air temperature and relative humidity were used to calculate vapor pressure deficit (VPD, kPa) (Rosenberg et al., 1983). Gravimetric soil water content on each sampling date was determined in soil cores at depths of 0-10, 10-20, 20-30, 30-40, and 40-50 cm using a soil sampling tube (SoilMoisture Equipment Corp.). Gravimetric soil water content was determined by drying soil samples in an oven at $105{ }^{\circ} \mathrm{C}$ for $72 \mathrm{~h}$, and was expressed on a dry weight basis $\left(\mathrm{kg} \mathrm{kg}^{-1}\right)$.

\section{Statistical analyses}

To determine if differences existed among shrub species in $\Psi \mathrm{pd}$ or $\Psi \mathrm{md}$ at each sampling date, water potential data were subjected to one-way ANOVA. Differences among species were validated using the Tukey's test and were considered statistically significant at $p<0.05$ (Steel \& Torrie, 1980) for all pair-wise comparisons. Assumptions of normality for $\Psi$ pd and $\Psi$ md were tested using the Kolmogorov-Smirnov test (Steel \& Torrie, 1980). Diurnal $\Psi$ changes among shrub species at different sampling hours were analysed with a repeated measures analysis design (RMANOVA) (Potvin et al., 1990), where shrub species represented the between-subject variable and sampling hour and the interaction shrub species $\times$ sampling hour were considered as within-subject repeated measurement factors. The Spearman's rank order correlation coefficient was used to measure the relationship between $\Psi$ and air temperature, relative humidity and vapor pressure deficit.

\section{Results and discussion}

Seasonal gravimetric soil water contents at the $0-10$, 10-20, 20-30, 30-40, and 40-50 cm soil depths are shown in Figure 1. Minimum soil water content (around $0.12 \mathrm{~kg} \mathrm{~kg}^{-1}$ ) in the five soil depth profiles were registered on Aug-10 while higher soil water content values ranged from $0.31(0-10 \mathrm{~cm})$ to $0.24 \mathrm{~kg} \mathrm{~kg}^{-1}(40-50 \mathrm{~cm})$ and were measured on Sep-20, which coincides with a peak rainfall. Soil water content variations observed in this study are in agreement with previous studies (Anderson et al., 


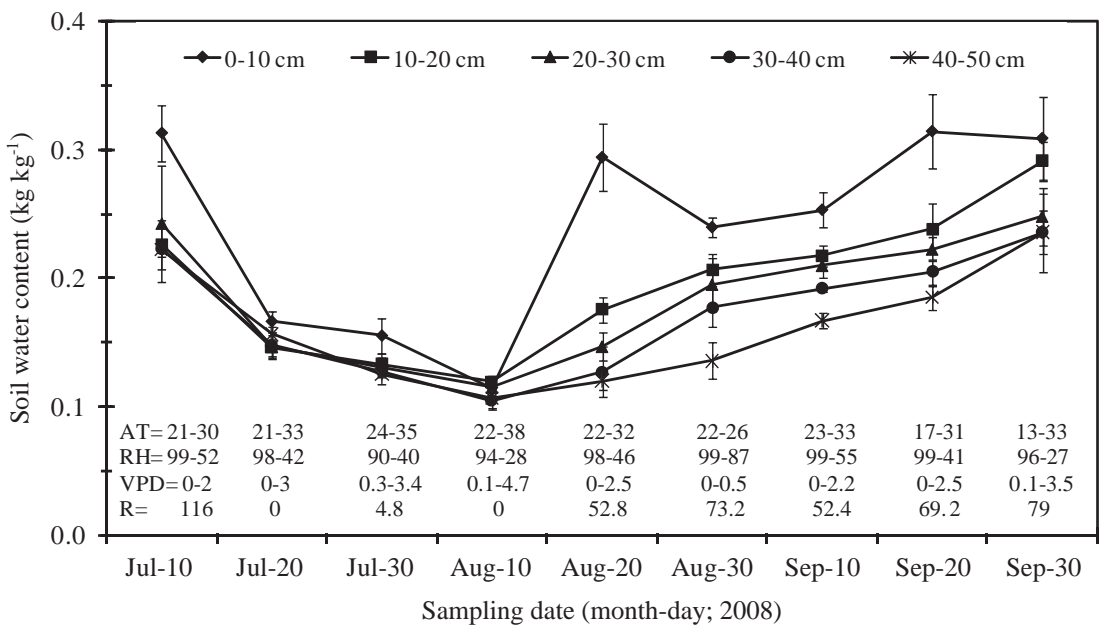

Figure 1. Seasonal variation in gravimetric soil water content at five soil profile depths at the research site. Values are means \pm standard errors $(\mathrm{n}=4)$. Diurnal range in air temperature $\left(\mathrm{AT},{ }^{\circ} \mathrm{C}\right)$, relative humidity $(\mathrm{RH}, \%)$, and vapor pressure deficit $(\mathrm{VPD}, \mathrm{KPa})$ and cumulative rainfall $(\mathrm{R}, \mathrm{mm})$ for a 10 -day period before each sampling date.

2001; Bussotti et al., 2002; Veneklaas \& Poot, 2003; González et al., 2004).

Monthly variation in $\Psi$ pd is shown in Figure 2(a). In general, data followed a similar pattern of varia- tion among shrub species when values were higher than $-1.0 \mathrm{MPa}$; meanwhile, this trend diverged among species, particularly in $Z$. fagara and E. texana, in which cases, observed $\Psi$ pd values
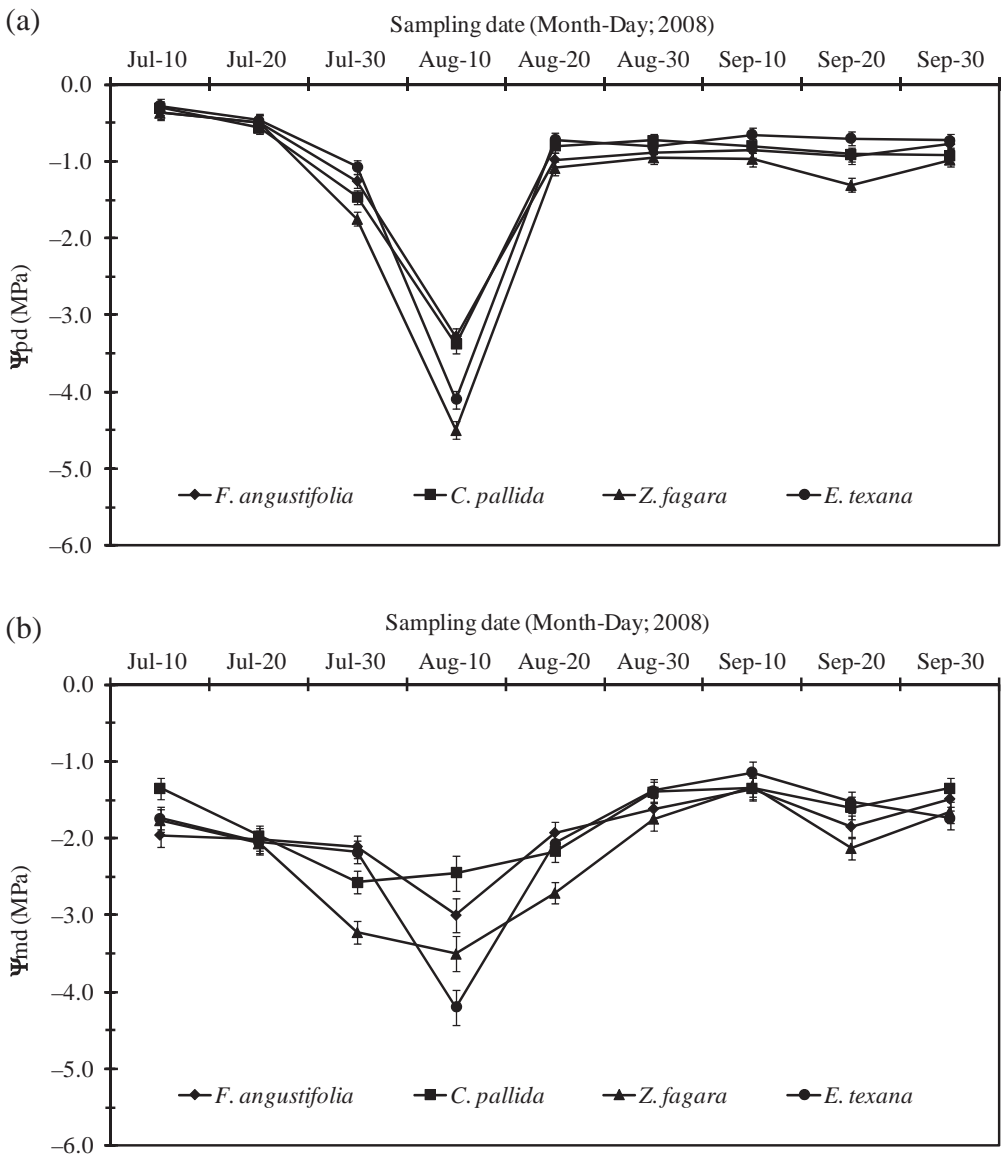

Figure 2. Seasonal variation in predawn (a) and midday (b) xylem water potential in four shrub species. Plotted values are means \pm standard errors $(n=5)$. 
declined below $-4.0 \mathrm{MPa}$. At the wettest sampling date, Jul-10, $\Psi$ pd values $(-0.28 \mathrm{MPa})$ achieved in E. texana and C. pallida ( $\Psi \mathrm{pd}=-0.37 \mathrm{MPa})$ and those detected in $Z$. fagara were similar. Conversely, on the driest sampling date (Aug-10), lower $(-4.5$ $\mathrm{MPa}) \Psi \mathrm{pd}$ values were observed in $Z$. fagara and $E$. texana suggesting that the former species are more susceptible to water deficits (Figure 2(a)).

Trends in $\Psi \mathrm{md}$ for the studied species are illustrated in Figure 2(b). Significant differences $(p<0.05)$ were detected among shrub species in four sampling dates (Jul-10, Jul-30, Aug-30, and Sep-20); however, no significant differences were observed in the remaining five sampling dates. On the wettest sampling date, when $\Psi$ md was the highest (Sep-10) and when soil water content at the soil layer between $30-50 \mathrm{~cm}$ was higher than $0.20 \mathrm{~kg} \mathrm{~kg}^{-1}$, $\Psi \mathrm{md}$ values ranged from -1.14 (E. texana) to $-1.35 \mathrm{MPa}$ (F. angustifolia); in contrast, on the driest sampling date (Aug-10), when soil water content was below $0.12 \mathrm{~kg} \mathrm{~kg}^{-1}$, maximum $(-2.45 \mathrm{MPa})$ and minimum $(-4.2 \mathrm{MPa})$ $\Psi \mathrm{md}$ were observed in C. pallida and E. texana, respectively (Figure (2b)). Clearly, among the species under study, $C$ pallida may be an example of a plant species which has adapted to low water availability by means which tend to maintain high tissue hydration, while the adaptation of E. texana to its dry environment seems to depend on strategies which allow it to cope with internal desiccation. Thus, our small group of experimental species included as wide a scope in this respect as can be encountered (Gebrekirstos et al., 2006). In either case, the underlying specific drought response mechanisms are currently the subject of our attention.

Diurnal $\Psi$ values in the four native shrub species and prevailing environmental conditions over the course of four sampling dates (Jul-10, Aug-10, Aug-30, and Sep-30, 2008, respectively) are shown in Figure 3. On these four sampling dates, RMANOVA detected a significant effect of shrub species $(p<0.01)$, sampling hour $(p<0.01)$, and the interaction species $\times$ sampling hour $(p<0.05)$, indicating that differences in $\Psi$ values among shrub species may vary among sampling hours. To this respect, in all species studied, $\Psi$ showed the typical diurnal time course, decreasing gradually from predawn maximal values until minima were reached at midday, after which $\Psi$ began to recover in late afternoon (Figure 3(a), 3(e) and 3(g)). However, an unusual $\Psi$ response is shown in Figure 3(c), which suggests that $\Psi$ is higher at midday in comparison with predawn. It is tempting to speculate whether this rare trend could possibly reflect a solute-enriched xylem content at the sampling time due to mobilization of cell sap from cells en route to abscise to reduce water loss under severe drought. In support of this notion, Donovan et al. (2003) reported disequilibrium between predawn soil and plant tissue (leaf and xylem) $\Psi$ in diverse mesophytes and xerophytes due to apoplastic solute build up. They concluded that predawn leaf $\Psi$ and xylem $\Psi$ may not reflect soil water potential, particularly for woody plants and halophytes, even under well-watered conditions. Additionally, accumulation of organic and inorganic solutes to lower the osmotic potential and thus drive on water absorption following a source to sink $\Psi$ gradient is well documented (Newton et al., 1991; Liu et al., 2003; De Micco \& Aronne, 2008).

On Jul-10, 2008 (Figure 3(a)), when plants experienced high soil water content, C. pallida showed significantly higher $\Psi$ values than those attained by F. angustifolia for most sampling hours revealing that the former could be considered as a water saver. A similar pattern was observed between studied shrub species on Aug-30, 2008 (Figure 3(e)). However, on Aug-10, 2008 (Figure 3(c)), when shrub species faced severe soil water deficit (Figure 1), higher $\Psi$ values were observed in $C$. pallida than those registered by $Z$. fagara and E. texana, which showed lower values. As a general trend, on Sep-30, 2008, $\Psi$ determinations were higher in $F$ angustifolia than those registered in $Z$. fagara (Figure $3(\mathrm{~g})$ ). Similar responses were also documented by Gebrekirstos et al. (2006) in shrub species from savanna woodlands in Ethiopia and by De Micco and Aronne (2008) in Mediterranean shrubs.

Under adequate soil water content $(>0.20$ $\mathrm{kg} \mathrm{kg}^{-1}$ ), the contrasting diurnal pattern of changes in $\Psi$ observed in the studied shrub species was strongly influenced by the daily course of atmospheric evaporative demand components (air temperature, relative humidity, and vapor pressure deficit). In fact, a highly significant and negative relationship between $\Psi$ and air temperature and vapor pressure deficit was detected. These findings agree with previous studies by Kolb and Stone (2000) in Quercus gambelii, González et al. (2000) in Acacia berlandieri, and González et al. (2004) in Havardia pallens, Acacia rigidula, Eysenhartia texana, Diospyros texana, Randia rhagocarpa, and Bernardia myricaefolia growing in Arizona, USA, and in northeastern Mexico, respectively. This cause-effect relationship tended to exhibit a Type I curve (Ritchie \& Hinckley, 1975), which suggests that under high soil moisture availability, the shrub species studied showed maximum $\Psi$ values at predawn and a minimum at midday, followed by a subsequent recovery in $\Psi$ overnight due mainly to low evaporative demand. If it is assumed at predawn (06:00 h) that $\Psi$ values represent a true equilibrium (close enough) with soil water potential (not determined in this study), the differences detected at this sampling hour between shrub species under high soil 

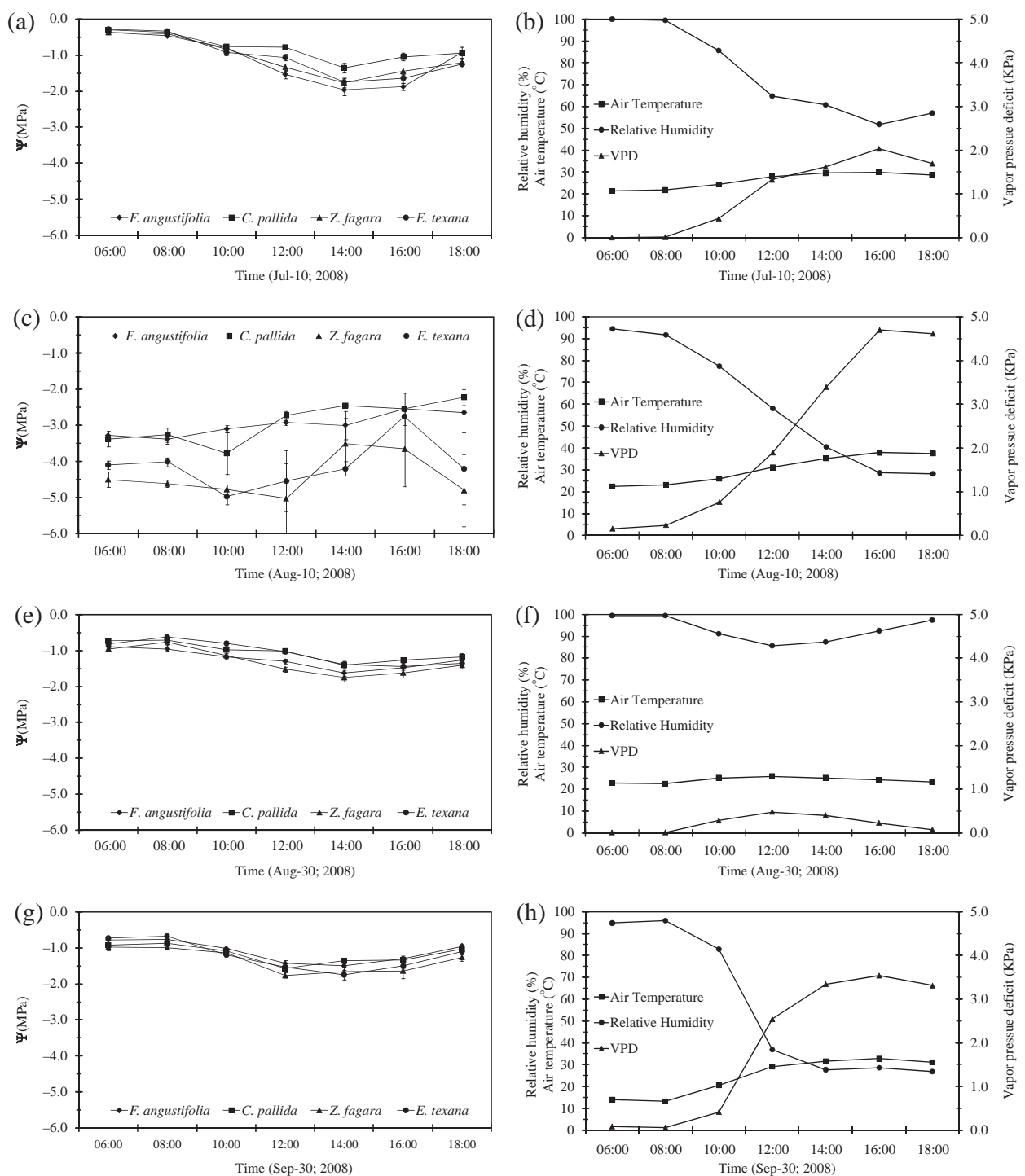

Figure 3. Diurnal course of xylem water potential $(\Psi)$ and prevailing environmental conditions of native shrub species sampled on Jul-10 (a and b), Aug-10 (c and d), Aug-30 (e and f), and Sep-30 (g and h), respectively. Xylem water potential values are means \pm standard errors $(\mathrm{n}=5)$.

water content registered on Jul-10 and from Aug-30 through Sep-30 (Figure 2(a)) could be explained by the resistance between the rooting medium and the root surface and plant (root, stem and leaf) hydraulic resistance. However, it has been documented that some shrub species such as Chrysothamnus nauseosus and Sarcobatus vermiculatus have exhibited predawn disequilibrium, defined as plant water potential at predawn substantially more negative than the water potential of soil accessed by roots; this phenomenon has been associated with nocturnal transpiration and putative leaf apoplastic solutes (Donovan et al., 2003). Whether or not this mechanism influenced the predawn water potential responses in the studied species remains unresolved. At midday, the differences detected among shrub species (Figure 2(b)) could be explained by the physiological differences among them, as the environmental conditions were the same. However, admittedly the root and stem hydraulic resistance, leaf stomatal conductance, the number of the conducting elements, stomatal density and the morphological and anatomical characteristics of leaves and stomata could have exerted important undetermined effects on the diurnal water relations of plant tissues in this study (Stienen et al., 1989; Castro-Díez et al., 2000; Bussotti et al., 2002).

On a seasonal basis, the gradual decrease in $\Psi$ pd (Figure 2(a)) and $\Psi \mathrm{md}$ (Figure 2(b)) for the four shrub species showed a considerable response to precipitation trends. Similar findings were reported by Montagu and Woo (1999), who determined the soil water availability pattern, with lower $\Psi$ pd or $\Psi$ md 
$(<-3.0 \mathrm{MPa})$ values occurring when soil water content reached values below $0.15 \mathrm{~kg} \mathrm{~kg}^{-1}$; however, both $\Psi \mathrm{pd}$ and $\Psi \mathrm{md}$ recover after the onset in rainfall. Among the species under study here, Z. fagara or $E$. texana would be at a physiological disadvantage compared with $F$ angustifolia or $C$. pallida, since the former two showed a significantly steeper decrease in both water potential parameters with respect to the latter ones, as shown in Figure 2(a). Furthermore, $C$. pallida is the only species which, under drought stress, tends to reach and maintain a higher water potential (desiccation avoidance response) than Z. fagara, since both $\Psi$ pd and $\Psi$ md measurements decrease earlier. It has been found that over the seasonal soil water depletion course, there is a concomitant reduction in both stomatal conductance (Montagu \& Woo, 1999) and water potential (Fotelli et al., 2000). This response may be viewed as a mechanism to conserve water and thus avoid tissue dehydration (Veneklaas \& Poot, 2003; Otieno et al., 2006).

\section{References}

Anderson, L. J., Brumbaugh, M. S., \& Jackson, R. B. (2001). Water and tree-understory interactions: a natural experiment in a savanna with oak wilt. Ecology, 82, 33-49.

Bussotti, F., Bettini, D., Grossoni, P., Mansuino, S., Nibbi, R., Soda, C., \& Tani, C. (2002). Structural and functional traits of Quercus ilex in response to water availability. Environmental and Experimental Botany, 47, 11-23.

Castro-Díez, P., Puyravaud, J. P., \& Cornelissen, J. H. C. (2000). Leaf structure and anatomy as related to leaf mass per area variation in seedlings of a wide range of woody plants species and types. Oecologia, 124, 476-486.

De Micco, V., \& Aronne, G. (2008). Twig morphology and anatomy of Mediterranean trees and shrubs related to drought tolerance. Botanica Helvetica, 118, 139-148.

Donovan, L. A., Richards, J. H., \& Linton, M. J. (2003). Magnitude and mechanisms of disequilibrium between predawn plant and soil water potentials. Ecology, 84, 463-470.

Fotelli, M. N., Radoglou, K. M., \& Constantinidou, H-I. A. (2000). Water stress responses of seedlings of four Mediterranean oak species. Tree Physiology, 20, 1065-1075.

Gebrekirstos, A., Teketay, D., Fetene, M., \& Mitlöhner, R. (2006). Adaptation of five co-occurring tree and shrub species to water stress and its implication in restoration of degraded lands. Forest Ecology and Management, 229, 259-267.

González, R. H., Cantú, S. I., Gómez, M. M. V., \& Jordan, W. R. (2000). Seasonal plant water relationships in Acacia berlandieri. Arid Soil Research and Rehabilitation, 14, 343-357.

González, H. R., Cantú Silva, I., Gómez Meza, M. V., \& Ramírez Lozano, R. G. (2004). Plant water relations of thornscrub shrub species, northeastern Mexico. Fournal of Arid Environments, 58, 483-503.

Kolb, T. E., \& Stone, J. E. (2000). Differences in leaf gas exchange and water relations among species and tree sizes in an Arizona pine-oak forest. Tree Physiology, 20, 1-12.

Liu, M. Z., Jiang, G. M., Li, Y. G., Niu, S. L., Gao, L. M., Ding, L., \& Peng, Y. (2003). Leaf osmotic potentials of 104 plant species in relation to habitats and plant functional types in Hunshandak Sandland, Inner Mongolia, China. Trees, 17, 554-560.

McMurtry, C. R., Barnes, P. W., Nelson, J. A., \& Archer, S. R. (1996). Physiological responses of woody vegetation to irrigation in a Texas subtropical savanna, pp. 33-37. La Copita Research Area: 1996 Consolidated Progress Report. Corpus Christi, Texas A\&M University System, College Station: Texas Agricultural Experiment Station.

Montagu, K. D., \& Woo, K. C. (1999). Recovery of tree photosynthetic capacity from seasonal drought in the wetdry tropics: the role of phyllode and canopy processes in Acacia auriculiformis. Australian fournal of Plant Physiology, 26, 135-145.

Newton, R. J., Funkhouser, E. A., Fong, F., \& Tauer, C. G. (1991). Molecular and physiological genetics of drought tolerance in forest species. Forest Ecology and Management, 43, 225-250.

Otieno, D. O., Kurz-Besson, C., Liu, J., Schmidt, M. W. T., Vale-Lobo do, R., David, T. S., Siegwolf, R., Pereira, J. S., \& Tenhunen, J. D. (2006). Seasonal variations in soil and plant water status in a Quercus suber L. stand: roots as determinants of tree productivity and survival in the Mediterranean-type ecosystem. Plant and Soil, 257, 295-304.

Potvin, C., Lechowicz, M. J., \& Tardif, S. (1990). The statistical analysis of ecophysiological response curves obtained from experiments involving repeated measures. Ecology, 71, 1389-1400.

Reid, N., Marroquín, J., \& Beyer-Münzel, P. (1990). Utilization of shrubs and trees for browse, fuelwood and timber in the Tamaulipan thornscrub, northeastern Mexico. Forest Ecology and Management, 36, 61-79.

Ritchie, G. A., \& Hinckley, T. M. (1975). The pressure chamber as an instrument for ecological research. Advances in Ecological Research, 9, 165-254.

Rosenberg, N. J., Blad, B. L., \& Verma, S. B. (1983). Microclimate: The biological environment (2nd Edn) pp. 170-172. John Wiley \& Sons, New York.

SPP-INEGI (1986). Sintesis geográfica del estado de Nuevo León. Secretaría de Programación y Presupuesto, Instituto Nacional de Geografía e Informática, México (in Spanish).

Steel, R. G. D., \& Torrie, J. H. (1980). Principles and procedures of statistics. A biometrical approach (2nd Edn). McGraw-Hill Book Company, New York.

Stienen, H., Smits, M. P., Reid, N., Landa, J., \& Boerboom, J. H. A. (1989). Ecophysiology of 8 woody multipurpose species from semiarid northeastern Mexico. Annales des Sciences Forestières, 46, 454-458.

Veneklaas, E. J., \& Poot, P. (2003). Seasonal patterns in water use and leaf turnover of different plant functional types in a species-rich woodland, south-western Australia. Plant and Soil, 257, 295-304. 